\title{
STUDENT PROTEST AND THE CULTURE OF VIOLENCE AT AFRICAN UNIVERSITIES: AN INHERITED IDEOLOGICAL TRAIT
}

\author{
DOI: http://dx.doi.org/10.17159/2223-0386/2017/n17a3 \\ Kehdinga George Fomunyam \\ Howard College, University of KwaZulu-Natal \\ kehdingag@ukzn.ac.za
}

\section{Abstract}

Since the advent of independence in African countries, education generally focused on transforming these nations and redressing the ills of colonialism. Education in countries like Ghana, and Kenya, amongst others aimed at redressing the colonial legacy by creating a new world order marked by equality, mutual benefits and participation. However, this drive for equality, mutual benefits and participation has been beset by several challenges, ranging from access to funding. The recent and most devastating challenge has been the wave of violent student protests that have swept across African universities over the past decade. These protests led to the destruction of university structures and public property, as well as disruption of educational processes. While the reasons for these protests have been different in different countries, they all have become violent. This article argues that the culture of violence exhibited by students and their advocates is an inherited ideological trait that is gradually manifesting itself among students. In support of this argument, student protest is examined in the five regions of Africa; North, South, East, Central and West, spanning more than 20 different nations. The article concludes that because the culture of violence is an inherited one, the process will continue unless urgent steps are taken to ensure transformation and decolonisation. It also argues that universities need to create environments where students are comfortable to learn, thereby eradicating the need for protest.

Keywords: Student protest; Violence; Africa; Universities; Ideological trait; Genopolitics.

\section{Introduction}

Student protest in Africa and elsewhere in the world is not a new phenomenon. On the African continent, widespread student activism arose in the early 1940s as African nationalism took different directions in the struggle for independence and took effective root after independence. Balsvik (1998) argues that students played a vital role in the second fight for liberation in Africa, that of democratisation. Adding to this, Radina (2013) notes that 
student protest played a prominent role in fighting racial segregation and discrimination in most parts of the world. In the United States of America, there have been several violent students protest in which students demanded for basic rights or necessities like the Harvard University in protest of 1766 christened the "Butter Rebellion", the Fisk University student protest of 19241925, the Berkeley student protest of 1964-1965, the Columbia University protests of 1968, and the Deaf President Now (DPN) protest of 1988 at Gallaudet University. These protests demonstrated how violent student protest can be regardless of the cause (Weiland et al., 2013). In Canada, the situation has not been any different; the 2004 and 2012 student protests proved that no matter what students are protesting for or against, incidents of violence are bound to occur (Giroux, 2013). According to Bellei et al. (2014) and Kubal and Fisher (2016), in 2011 students in Chile staged a seven months long protest which saw several violent confrontations with the forces of law and order although it eventually led to a change in the public education agenda. In France, student protest was not only violent but became bloody in what has been christened "Bloody Monday". In 1968 France was on the verge of a total revolt and on May 6, 1968, the violence took another direction with 422 students arrested and 345 policemen injured. The next day, students outsmarted the police and barricaded the road and continued their protest (Duhan, 2013). The Velvet Revolution of 1989 in former Czechoslovakia which was predominantly a peaceful demonstration became violent when students began to protest. On November 17 and 181989 students demonstrating in Prague clashed with security forces and they were brutally suppressed with hundreds of students injured (Kurtz, 2008). In China, the student protest had been gathering momentum since 1986 and reached its peak in 1989 amidst nationwide protest in China. The Tiananmen Square Massacre of June 41989 saw the killing of tens of students who alongside others attempted to block the military's advance towards Tiananmen Square (Kim, 2008). Although these instances of violent student protest across the world started for different reasons and took different directions, they had one thing in common, violence.

In Africa, since the 1960s, there have been waves of student protest in almost all African nations in response to social, economic, cultural, political, and personal injustice (Fomunyam \& Rahming, 2017). Teferra and Altbachl (2004) observe that these protests have been triggered by poor student services, delayed receipt of stipends (where they are offered) and the termination of student benefits. Although the protests have taken different forms (Amutabi, 
2002), most have been violent. The cases of South Africa, Cameroon, Nigeria, Kenya, Egypt, and Tunisia amongst others are practical examples of violent student protest that led to the death and imprisonment of some individuals. Federici and Caffentzis (2000:140) state that "there were over a total of 110 reported student protests in Africa between the years 1990 and 1998 and because of the violent nature of these strikes, government responses to student protests were 'inhumane', 'brutal', and 'excessively cruel'".

Konings (2002) adds that the wave of political liberation in Africa that began in the 1980s led to an unprecedented wave of student protest in universities across West and Central Africa. Students were at the forefront of struggles for political liberalisation, and sometimes received support from secondary school students, their teachers, and other professional groups. Kohstall (2015) argues that student protests in Egypt and Morocco were an integral part of the Arab uprisings in 2011. Dissatisfaction with universities' social policies and authoritarian regimes led to violent protests and many deaths. David (2013) further notes that, violent student protests in Nigeria over the past 30 years have led to diverse changes in the educational and political landscape of the nation. According to Gerbaudo (2015), protest avatars have emerged; people portray pictures or images of those who died to demonstrate their support for what they died advocating for.

Students have damaged property, destroyed university structures, and even attacked one another (as was the case in Cameroon) (Konings, 2002). When this happens, most governments respond by deploying forces of law and order and the violence ensues often leaving some students and law enforcement officers' death or injured. The causes or reasons for such violent behaviour can be understood from different perspectives. This paper is an attempt to explain this phenomenon as an inherited ideological trait. This is not to say that this is the only reason for the culture of violence in student protest. It is rather a single attempt to explain the phenomenon on the African continent. To this effect, this article is an exploration of student protest and the culture of violence at African universities as an inherited ideological trait. To effectively do this, it is vital to discuss the African geopolitical landscape, the ideological trait, and the concept of genopolitics.

\section{African geopolitical landscape}

The history of Africa is a complex one with almost the whole continent, except for Ethiopia and Liberia, having been colonised by European powers. 
From the late 1500 s to early 1600 , the Portuguese began exploring the coast of Africa and other European powers followed (Asante, 2014). The scramble for Africa officially began during the 1800s, which led to the Berlin West African conference of 1884 (where Europeans attempted to divide Africa amongst themselves) and eventually the colonisation of Africa, although other nations like South Africa were colonised before this period. Bening (2014) opines that there was strong resistance to colonial rule in Africa, before the First World War, although the colonizers supressed such with ease in most cases. The struggle for independence in Africa began following the formation of the United Nations (UN) at the end of the Second World War (Njoh \& Bigon, 2015). This struggle took different directions in different African nations. For some, independence was peacefully negotiated, while for others it was the bloodiest battle ever witnessed in Africa. Examples of the latter include the Algerian war of independence led by the National Liberation Front and the Cameroonian war of independence led by the Union of the Peoples of Cameroon (DeLancey et al., 2010). Nonetheless, across the continent, some form of armed conflict existed between the colonial masters and the colonised prior to independence (Kovač, 2016). Kovač (2016) notes that resistance to colonial rule was mainly driven by the philosophical 'ideal' of Marxism. This ideology identifies two classes of people in society, the oppressed and the oppressor. The colonial masters were seen as the oppressors while the masses were identified as the oppressed.

In the wake of independence, a wave of disillusionment swept across African nations because most citizens believed that their expectations had not been fulfilled (Isaacman, 1990; Malila \& Garman, 2016). The African elite that assumed power was regarded as an extension of the Europeans, especially since many had studied in Europe and America. As a result of such disillusionment, citizens in different nations started protesting as a way of demanding better socio-political amenities and realities. In different nations, such demand for improved socio-political conditions took different directions while some were protesting, others experienced waves of revolutions, coup d'états and civil wars. Practical examples include the Union de Population Cameroonaise (UPC) revolts in Cameroon in the 1960s and 1970s, the Biafran civil war in Nigeria and the Katanga secession in Congo. Between 1960 and 1969 there were a total of 21 coup d'états in Africa (Isaacman, 1990). The number of revolutions and protest was exacerbated by the economic crisis that plagued Africa in the 1980s. In the late eighties and early nineties another wave of revolutions occurred across the continent, giving birth to what is commonly 
referred to as democratic Africa (Zeilig \& Dwyer, 2012) or multi-party politics as in South Africa, Cameroon, Mozambique, Angola, and Nigeria.

Therefore, since the time of colonisation, African nations have been struggling to liberate themselves from one form of bondage or another. African nations have a history of resistance and this history has repeated itself repeatedly whenever socio-economic or socio-political conditions within such nations were not encouraging. Most Africans that are part of the proletariat see themselves as being oppressed by the superstructure and desire freedom and this desire amongst other things through community organisations has led to the creation of "socio-political entities, with their own rules, forms of organisation and internal hierarchies, constituting a node of resistance and defiance against state domination" (Cheru, 2002:48). To further clarify this, it is vital to look at ideology and the predominant ideological construct which informs protest or resistance.

\section{Ideology}

Marx and Engels (1980) maintain that ideology is the production of ideas, conceptions, and consciousness. It refers to all that people say, imagine and conceive about life. Abercrombie et al. (2012) citing Marx and Engels (1980), see ideology as the superstructure of a civilisation or the conventions and culture that make up the dominant ideas of a society. Marx and Engels (1980:64) argue that the:

... ruling ideas of a given epoch are, however, those of the ruling class, the ruling ideas are nothing more than the ideal expression of the dominant material relationships or ideas, hence of the relationships which make the one class the ruling one, therefore, the ideas of their dominance.

Žižek (1999) maintains that ideology is not an illusion, or a mistaken or distorted representation of society, and is not necessarily false. Rather, it can be true and quite accurate, since what really matters is not the asserted content as such, but the way this content is related to the subjective position implied by its own process of enunciation. Žižek (1999) adds that ideology is a complex web of ideas (theories, convictions, beliefs, and argumentative procedures), a doctrine, a composite of ideas, beliefs, and concepts that aims to convince us of its truth, yet serves unavowed power interests. These definitions indicate that ideology is not innocent, but aims at serving a particular interest or purpose. 
According to Magzan (2009), Marxism as propounded by Karl Marx regards ideology as a false consciousness. He sees it as a false consciousness because society is stratified into different groups or classes and a person's membership of a group causes him or her to see and experience the world through the lens of that group or class. As such, it is almost impossible for an individual member of a group or class to form a conception of the world because he or she only sees the world through a tiny lens. For Marx, therefore, ideology shapes the way we think and see the world. Members of different social classes are taught and brought up to think and see the world through a lens that is appropriate for that class. Marx refers to this as the social construction of reality that is largely shaped by the social world we live in. If one were to change one's class, one would perceive reality differently. Thus, Marxism propounds that it is often difficult to break free from the grip of the superstructure because its established institutions of socialisation such as schools, churches and others indirectly ensure the continuity of the hegemony (Magzan, 2009). Ideology prevents people from understanding the socio-economic realities in their society which can help them change class, thereby creating a new reality which becomes the core of their lives. This new reality is a false consciousness which produces psychologically satisfying symbols and brings assumed order to the world.

In the contemporary world where poverty and misery are on the increase as well as the prices of basic commodities, students find it difficult to cope with the circumstances in which they find themselves. Some students blame their forebears for this, while others choose to create their own pathways. Better still, some of them choose to follow the example of their forebears, striving to resist the same forces their forefathers resisted for centuries. While colonialism is said to have ended in Africa, neo-colonialism has taken over, and many African youths still feel colonised. The wave of revolts in Africa in the eighties and nineties brought about by several factors like poor service delivery in Nigeria, economic crisis in Cameroon, amongst others remain prevalent, which explains the wave of student protest across the continent in recent times. For this to be theorised more clearly, a regional approach is adopted, with different student protest action in different nations within different regions (North, South, East, West, Central Africa) discussed alongside its causes and what occurred in the past. But before that, it is vital to explore the lens of genopolitics and its baseline arguments 


\section{Genopolitics}

Genopolitics as an area of inquiry came to the forefront in scientific research with the publication of Eaves and Eysenck (1974) article on how genetics influences social attitude and behaviour. Martin et al. (1986) picked up the trend 12 years later arguing that social attitudes are transmitted from one person to another genetically. Eaves et al. (1989) further enhance this discourse on how genetics enhance political behaviour. Biuso (2008) argues that the term genopolitics was originally coined by James Fowler in 2005 to describe how genetics shape political behaviour. Hatemi and McDermott (2012b) went further to argue that genetics doesn't only shape political behaviour, it also shaped or determined violence in politics. Hatemi and McDermott (2012a: 526) argue that research in genopolitics indicated that:

... genetic influences could be statistically equated across populations and measures. This suggests that the relative importance of genetic influences remains common across cultures, but the relative influence of family and personal environments varies greatly across societies, time, and measures in explaining the variance in attitudes.

This goes a long way to suggest that genes do not directly affect specific attitudes, but rather genetic propensity influences the disposition and operation of an emotive condition, which then manifests toward many targets, including strangers and out-groups, when elicited. Smith et al. (2011) trace the different ways by which genetics could ultimately connect to political attitudes and suggest that central to this connection are chronic dispositional preferences for mass-scale social rules, order, and conduct which they label as political ideology. They further argue that heritability of specific issue attitudes could be the result of the heritability of general orientations toward bedrock principles. As such there is a link between genetics and ideology as well as the ideological dispositions of young adults and their parents.

The idea that ideology or political behaviour is inherited is further buttress by Hatemi et al. (2014) in their study comprising of more than 12,000 participants brought together through nine different studies, conducted in five democracies, and sampled over the course of four decades. They emphatically argue that genetic factors play a role in the formation of political ideology, regardless of how ideology is measured, the era, or the population sampled. They present results from one of the first genome-wide association studies on political ideology using data from three samples: a 1990 Australian sample involving 6,894 individuals from 3,516 families; a 2008 Australian sample of 1,160 related individuals from 635 families and a 2010 Swedish sample 
involving 3,334 individuals from 2,607 families. And these results indicate that political ideology constitutes a fundamental aspect of one's genetically informed psychological disposition.

Genopolitics as an area of inquiry has not gone without criticism. Charney and English (2012) argue that the problem with genopolitics is that a large set of genes, the transcriptional activity of which is influenced by the environment and each other's functional products, is incompatible with the expectation that two genes could predict political behaviour. They add that proteins encoded by at least 266 genes are involved in variation in aggression in fruit flies, yet at the same time, the heritability of aggression is less than -0.1 because of the high level of environmental variance (even though the researchers assumed the environments were identical). They conclude that "we have the strongest reasons to doubt that a handful of candidate genes will provide a meaningful key to understanding differences in voting behaviour, political ideology, or attitudes toward abortion" (p. 30). In response to this criticism, Fowler and Dawes (2013) argue that genopolitics has already made a lasting contribution to the field of political science and advancing the field requires conducting open empirical studies that lay out the advantages and disadvantages of the methods used to measure the world. Other strong critics of genopolitics are Joseph (2010) and Shultziner (2013). Joseph (2010) posits that political scientists have claimed that differences in political orientation and behaviour have an important genetic basis. However he goes further to refute this claim by arguing that the main theoretical assumption of the findings of the research is premised on the idea that monozygotic and dizygotic of twin pairs experience equal environments. This to him is untenable, as such the results of twin studies can be completely explained by non-genetic factors. $\mathrm{He}$ questions the methodology used in arriving at such findings. Shultziner (2013) on the other hand, argues that the results of twin studies in political science that supposedly disclose a genetic basis for political traits, is not justified. This is because identical twins tend to be more alike than non-identical twins. As such the former are more similarly affected by the same environmental conditions, but the content of those greater trait similarities is nevertheless completely malleable and determined by particular environments. As such the twin studies method, thus can neither prove nor refute the argument for a genetic basis of political traits. Although Joseph and Shultziner are both critics of genopolitics, they present contradictory ideas. Joseph argues that the premise that twins experience equal environments is untenable, while Shultziner argues that identical twins experience or are affected by the same 
environmental conditions. To Shultziner twin students can neither refute nor prove genetic basis. While the disagreement between the two is part of the gap genopolitics is trying to fill, genopolitics is not entirely based on twin studies. Hatemi and McDermott (2012a) used several households with data generated over a period of forty (40) years, spanning over five nations. The fact that the findings of their study was in favour of genopolitics and that this study is yet to be disproved empirical dictates the validity of its findings. Furthermore, the critics of genopolitics do reject the existence of such genes but rather debate its influence. While genes can be shaped by environmental factors, the existence of the gene itself cannot be questioned since Shultziner takes about its supposed influence having other explanations. In defence of genopolitics, therefore studies like Hatemi et al. (2014), Kurbatova (2017) and Beattie (2017) amongst others all conducted after these criticism revalidate the claim that genetics influence political behaviour. Beattie (2017:10) concludes his study with the view that "like most traits, political ideology is produced by the complex interplay of genetic and (social/informational) environmental influences". Such criticisms rather than void the validity of the field, point to different pathways or pitfalls which need to be strengthened and which presently is being addressed, for all fields or areas of inquiry like qualitative research have once suffered serious criticism. To this effect, employing genopolitics as a lens within this study is a step in the right direction because the argument here is not the degree of influence of genes which sociobiologist and evolutionists are still busy with, but rather that there is an influence. The application of this lens to explain the culture of violence in student protest in African universities is not generalising or going beyond the boundaries articulated by Eaves and Eysenck (1974) but rather seeking an understanding in line with Hatemi and McDermott (2012a), Eaves et al. (1989), Martin et al. (1986), Maxfield and Widom (1996), Smith et al. (2011) and Charney and English (2012). This would be done by exploring the phenomenon in the five regions of Africa; North, West, Central, East and South Africa.

\section{North Africa}

North Africa is a made up of seven nations and a disputed territory, Western Sahara. The majority of its inhabitants speak Arabic (Halpern, 2015). In the past, these nations experienced different types of conflicts, both violent and peaceful. The whole of northern Africa was colonised by the British and French and the indigenous peoples protested violently to gain their independence. 
As noted earlier, the most striking struggle was the revolt in Algeria. Zeleza (2012) argues that in Northern Africa in particular and Africa in general, there were two major types of war or conflict. The first involved the use of both guerrilla and conventional approaches to deal with opposing forces. Well-established or centralized organisations and states adopted conventional approaches and, if defeated, embarked on guerrilla warfare. These revolutions in the 1950s and 1960s in places like Egypt, Algeria, and Libya, which led to Gaddafi's rise to power, as well as Morocco, Tunisia and Sudan (Sudan was yet to be divided into Sudan and South Sudan and Western Sahara had yet to be established) all aimed to improve the socio-economic lot of the people in a society where they were denied their basic needs. Beissinger et al. (2012) argue that there are several reasons for the recent uprisings in North Africa, including poverty, tyranny and exploitation. They add that the African ruling classes or the elite that holds power have enriched themselves and become the targets of envy or rivalry by other elite groups and the youth who want their share of the national cake. These elites have commercialised politics and made it a venture in its own right.

This partially explains why students were part of the Arab Spring which was one of the most violent conflicts Northern Africa has witnessed in recent times. Gorgas (2013) observes that students were an integral part of the revolution due to the scarcity of resources at universities, constant increases in tuition fees, deplorable living conditions and hunger. Anderson (2011) adds that more than $40 \%$ of protesters in North Africa during the Arab Spring were students. She adds that the basic expectation that children would grow up, begin to contribute productively to society, and then raise families of their own was not fulfilled for an entire generation of youth in the Arab world trapped in a period that is often referred to as "waithood". Indeed, the revolution in Tunisia was spearheaded by Mohammed Bouazizi, a young newspaper vendor who set himself alight in public in 2010. The violent start to this protest led to bitter battles between the protesters and the forces of law and order. In Egypt, schools were closed and a curfew was declared. Students defied the order and continued to protest. They destroyed government property and took on government forces, as well as those supporting the government. In Libya, Algeria, Sudan and Morocco, student protest took different forms though all involved one form of violence or another (Gerbaudo, 2015; Halpern, 2015). Kohstall (2015) postulates that in February 2011, hundreds of thousands of Moroccans turned out in major cities for what organizers termed a Movement for Change and the protests spawned the February 20 Movement a loosely 
organized, leaderless network that subsequently held large demonstrations criticizing Morocco's governance and advocating for political change. Collado (2013) further adds that the protest became violent and security forces then resorted to violence and arrests to disperse the demonstrators, most of whom were students. Amine (2015) concurs and points to the fact that in November 2014, Moroccan police officers in plainclothes arrested 10 students outside the Ibn Tofail University in the city of Kenitra because of the violent nature of the protest. The protest erupted as a result of the increased cost of transportation from student dormitories to school. From the beginning of the academic year, Ibn Tofail University witnessed a series of student protests against the "Al-Karama" company which increased the price of bus tickets. Earlier in the year, in January, a student was killed in clashes with the police at the university when students held a protest against the high cost of food and accommodation.

The situation was no different in South Sudan and Sudan. Hale and Kadoda (2014) state that South Sudan's breakaway from Sudan was partly due to the student demonstrations which took place across the nation. Zambakari (2014) adds that in 2011 students protested at the Red Sea University in Port Sudan due to the mass arrest of Darfuri student leaders; this led students to pledge open support for the Sudan Revolutionary Front. Furthermore, 700 student demonstrators at the University of Khartoum were arrested after a clash with the police, with several killed and many wounded. These students continued to launch violent protests against the economic regulations planned by President Omar Al-Bashir. Riot police used tear gas and batons against the protesters who in turn threw stones at police. On 11 July 2012, Sudanese university students armed with sticks and stones staged one of their largest protests since the unrest began. Lyons (2008) argues that young people are likely to imitate their parents' behaviour either immediately or in the future. This is supported by Smith et al. (2011) who maintain that specific attitudes like violence could be the result of the heritability of general orientations toward certain situations in life. In a region like North Africa where violent conflicts have been the order of the day (Egypt's on-going involvement in the Arab-Israeli war, the brutal suppression of protests and revolts in Egypt, Libya, and Tunisia, violent struggles for independence, and constant terrorist attacks), the youth are reproducing or imitating the violent footsteps of their forebears as the way to solve their challenges. 
The cycle of violence which students' parents generated or inherited (since they could have inherited this trait from their parents who also had a violent past in the form of the brutal tribal wars fought in Africa, violent wars to resist colonialism, European penetration into the hinterland, and Africa's involvement in the First and Second World War, amongst others) has been inherited by the current generation; this is evident in every mass protest they engage in. Although in some parts of the world people have succeeded to live in peace despite their violent ancestral past like the Norwegians and Danes' peaceful existence despite their Norseman ancestry, this doesn't negate the existence of such genetic traits in them. It simply presupposes the regulation and domination of such traits by environmental factors (Hatemi et al., 2014). In Africa such traits are provoked to manifest itself by socio-economic challenges as well as political instability which has been the cause of these crisis. Mamdani (2003) argued that the 1959 Revolution in Rwanda was the principal cause, amongst others, of the 1994 genocide as without the 1959 Revolution, there would never have been a civil war and without the civil war, the genocide would not have taken place. The ideological imprint of the 1959 Revolution led to the genocide. Consequently, the culture of violence displayed by African students is the result of inherent ideological traits they picked up from their parents. The situation in West and Central Africa further buttresses this argument.

\section{West and Central Africa}

West Africa is made up of 17 nations, while Central Africa includes seven. These regions have witnessed violent mass student riots for different reasons in past decades. Omonijo et al. (2014) note that there have been several student protests at Nigerian universities, including the Universities of Nsukka, Nigeria, Lagos, Ilorin, Ibadan, Jos and Port Harcourt. This led to the temporary closure of these universities and the death of several students. Abah and Folarin (2016) state that students at the University of Lagos shut down the campus on 6 and 7 April during protests against the lack of basic amenities. They chased students from hostels, mounted barriers at the university gates and clashed with police until the Senate was forced to close the institution to allow the situation to normalise. Abah and Folarin (2016:2) further add that:

Senate noted that the problem of poor municipal services is a national issue that governments at both state and federal levels are addressing. However, in order to forestall a further breakdown of law and order on campus, Senate resolved to take the following decisions until the situation normalises: All academic activities on 
campus are hereby suspended with immediate effect. The university is therefore closed with immediate effect. The statement ordered that students living on the campus should vacate their halls of residence, adding that no student should remain in the halls of residence after 10am on Friday, 8th April.

Ugbodaga (2016:1) confirmed the violent nature of student protest when he reported that:

Activities at the University of Ibadan (UI), were paralysed this morning (April 26, 2016) as thousands of students went on the rampage and shut down the school over management's victimization of a student who took part in a recent protest. The students, who stormed the school's main gate early in the morning shut it down immediately. They were also angry that power supply in the institution is still very epileptic while there is no water in the hostels. The students, who were chanting 'aluta' songs, dared security men attached to the gate to do something stupid as they were ready to descend on any of them. They vowed that the school gate would remain shut until the school's management reversed its decision...

As noted earlier, it is clear that students at African universities have inherited the culture of violence generated by the previous generation during the colonial era or the fight for independence. This is confirmed by the situation in Ivory Coast where students have been protesting over a lack of housing. The violent nature of the strike caused the government to shut down the university for two years; 18 months after it reopened, the strike began again (MacGregor, 2014). Today's youth are reproducing Ivory Coast's violent past, encapsulated in 33 years of repressive rule by Félix Houphouët-Boigny, the numerous coup d'états after his death, and civil wars, amongst others. Lyons et al. (2011) argue that when people observe a causal irrelevant action performed by those they look up to, they revise their implicit understanding of the causal relations behind the demonstration and, consequently, interpret the action as causally relevant. This leads them to faithfully reproduce or model such behaviour even in cases where the rest of the world regards it as unnecessary or irrelevant. Fomunyam and Rahming (2017) cite the reaction of a lecturer to the resignation of the German Chancellor on the grounds of academic plagiarism. The lecturer pointed out that "Even their high-powered leaders do it over there, so why is it a big deal here?" (p. 1). This affirms that people are generally uncritical of the actions of those they look up to, as a result, they model such behaviour. The violence manifested by students at African universities is therefore the result of an inherited ideological trait which unfailingly manifests in the lives of those who inherited it.

Karmo (2016) notes that students at the University of Liberia gathered at the entrance of the Capitol Building to protest against a proposal to increase 
tuition fees from \$175LD (approximately US\$2) to US\$4.00. The students petitioned lawmakers to intervene and asked them to increase the University's funding to US\$29 million in order to enable it to meet its growth and development agenda. They destroyed public property and fought with the police. MacGregor (2011) states that the government of Togo shut down the University of Lomé after two days of continuous student protest against the introduction of educational reforms anchored on the Bologna process, and the constant presence of security forces on the University campus to curb student violence. Nine students were injured, two seriously. Furthermore, there was substantial damage to university property. The students demanded the re-introduction of remedial courses and grants as well as a complete halt to the reforms known in French as LMD (licence, master, doctorate) and BMD (bachelors, master's, doctorate) in English for the three, five and eightyear degree levels, a system which has been instituted in Cameroon and other African countries. In shutting down the University, its leadership argued that the demands were "complex" and presented a "real problem"; it was impossible to meet them. The police who were brought in to curb student violence responded with teargas, turning the protest into a battle between students and the police.

On 10 and 11 April 2000, thousands of Gambian students took to the streets to protest against the death of a high school student, who was allegedly tortured by security force members, and the reported rape of a 13-year-old girl by a police officer (British Broadcasting Cooperation, 2000). They gathered at the gate of the Gambia Technical Training Institute to march to the city centre. Police ordered them to disperse as they had no permit to protest but the students refused. The police attempted to disband them using teargas, but the students later regrouped, setting up barricades with burning rubber tires in the streets and throwing stones at the police. Government buildings were attacked, a police station was set on fire and stores were looted. The police retaliated with live ammunition, killing at least 14 students and wounding more than 20 who had to be admitted to hospital, while countless others suffered light wounds (British Broadcasting Cooperation, 2000). Students also boycotted classes at the University of Nouakchott in Mauritania. Police arrested 16 students during clashes between students and police on the campus (Arabic). The national students' union (UNEM) has been a key force in organizing student protest action. The students' demands include quality of life issues (French), but the clashes added other demands to the list: the return of expelled students and "de-militarization" of the campus, etc. As 
perceived mistreatment by the police becomes one of the protesters' chief complaints, the protests are taking on a self-perpetuating logic.

The Maxfield and Widom (1996) study in the US which canvassed the views of about 900 young people revealed that those who had been abused by their parents or lived with parents or relatives who were violent were more likely to be violent in the future. Thus, children learn by example from their parents or relatives and practice what they learn. They see violence as the only legitimate way to solve challenges. The study thus revealed the transmission of aggressive and violent behaviour from one generation to another. Cameroon is a case in point. Its war of independence against the French was the bloodiest in Africa, comparable only to the Algerian experience. After independence and the plebiscite, post-independence disillusionment led to several waves of protest and revolts against the then president Amadou Ahidjo, led by UPC militants. Their violent suppression, the attempted 1984 coup d'état, and the brutalisation of citizens by the president who has held power for 34 years sparked a series of violent student protests. Konings (2002) points out that between 1990 and 1996 there were a series of violent student demonstrations at the University of Yaounde I in Cameroon which not only caused the death of more than five students but the wanton destruction of property. The university was made ungovernable, forcing the government to split it into two; Yaounde I and II. The University of Buea was also created to depopulate the university and reduce the chances of student protest. Chimanikire (2009) adds that in 2003, students at the University of Buea took to the streets to protest against deplorable living conditions in the university environment. The strike soon became violent, leading to police intervention and the eventual deposition of the governor of the region where the university is located. About two weeks later students caught and burnt alive an alleged bandit who was amongst those making the university environment deplorable. In 2005, 2006 and 2008 students at this university launched several protests, leaving six dead and hundreds wounded and imprisoned. In 2005 and 2006 the administrative building at the University of Buea was destroyed as were several cars, police vans and an ambulance. In 2013, the violence was repeated and would have gotten out of hand had it not been for brutal police intervention. Since October 2016 there have been no school in the anglophone regions of Cameroon due to student protest and constant clashes with the police (Fomunyam, 2017). 
Smith et al. (2012), Bell et al. (2009) and Hatemi and McDermott (2012a) argue that behavioural genetics has scientifically proven that political ideologies, and political or attitudinal orientation are inherited. Smith et al. (2012) further note that, while no specific gene for a preference or ideological orientation exists, biological systems built by genes play an important role in mediating political attitudes. Genetically speaking, political attitudes (which deal with the will to act in a particular way as well as the desire to make certain choices) are inherited. The culture of violence is one such ideological trait inherited by African students and they are demonstrating that this is the case. This is not peculiar to North, West or Central Africa, but also occurs in South and East Africa.

\section{South and East Africa}

Southern Africa is no exception to violent student protest. Prosser and Sitaram (2014) argue that the student protests which reached their peak in 1990 in Swaziland and have since continued, often started as a "disorganised demonstration against campus issues such as poor food" (p. 12) but soon turned into violent demands for democratic reform. The violence that ensued after soldiers swept through university campuses will always be a sensitive subject with government. The report of the commission set up to investigate the violence was kept secret for years, with a bowdlerized version finally released to the public in 1997 . Two of the students who were seriously injured sued the government for damages, and their cases were settled out of court. In 2011 another violent student strike broke out in Mbabane where students protesting against the closure of their university threatened to derail a traditional festival. They tried to breach a police cordon in Ezulwini at the start of the annual Umhlanga or Reed Dance, when thousands of women gather to perform before King Mswati III. This violent confrontation led to the arrest of seven students and several others were injured (Rooney, 2011).

Students at Lesotho's Limkokwing University have launched on-going protests against what they called bad management and poor services (Khama, 2010). Other grievances include slow internet speed and delays in disbursing their allowances (Khama, 2010). The Moeketsi Pholo Student Representative Council at the University pointed out that, "We have been submitting these issues to our management but nothing has been done to solve our grievances. So, the only option we have is to protest... and instead of solving our problems, the management is threatening us. As such we have no choice but to respond in kind" (Khama, 2010). 
Mfula (2016) notes that the University of Zambia and Copperbelt University were closed indefinitely by the Zambian government after student protests against non-payment of allowances turned violent. Scores of students were arrested. Higher Education Minister, Michael Kaingu justified this action in parliament by stating that, "the decision to close the universities had followed days of destructive protests during which public property was damaged" (Mfula, 2016:1). He added that some students burned tires and used logs to barricade roads, and vehicles were stoned. About 56 students were arrested. The minister appealed to student leaders to ensure that protestors were disciplined and non-violent. Much effort had been made to negotiate with students and persuade them to return to class, but this proved futile. The University of Zambia had assured students that the government was acting on their grievances, but they still resorted to damaging property. Kaingu told parliament that the permanent secretary of the ministry had intervened as soon as protests had begun, to no avail. The minister visited Copperbelt University and "offered to dialogue with students but they refused" (Mfula, 2016:1). Zambian President Edgar Lungu was quoted by the Lusaka Times as saying that the closure of the two universities was "a good lesson for the students" (Lusaka Times, 2016:3)

Lea (2013) notes that modern theories of crime and violence weave social and biological themes together. He adds that at least 100 studies have shown that genes play a role in crime and violence. Genes are ruled by the environment, which can either mute or aggravate violent impulses. While many people that have a genetic tendency towards aggression will never throw a punch, others that lack this tendency could become career criminals depending on the environment in which they find themselves.

In the contemporary period, almost all countries in Africa have been plagued by revolts and protest. South Africa is no exception. The country witnessed violent student protests at almost all its universities. Bawa (2016) posits that the University of Johannesburg alone suffered damages amounting to more than R100 million because of violent protest actions. The violence at South African universities escalated from damaging statues and artwork and confrontations with security staff and police, to the burning of buildings and brutal clashes between student factions. This violence is a legacy of racial discrimination and colonialism, high levels of unemployment and pronounced and increasing income inequality. The protests began at Tshwane University of Technology early last year, when students with outstanding 
debt were prevented from registering. The financial dilemma in which many students found themselves was exacerbated by the inability of the state loan and bursary agency - the National Student Financial Aid Scheme (NSFAS) - to meet its commitments. The protests spread to other campuses, taking different forms. Students at three universities in the south were the next to act. At the University of Cape Town, they took issue with the legacy of colonialism, symbolised by the memorial to Cecil John Rhodes, while those at Stellenbosch distributed a powerfully evocative film - "Luister" (Listen) - that documented black students' daily experiences of racism and discrimination (Hall, 2016). In the on-going protests, some students were arrested and some injured. At the University of Cape Town, protesting students torched vehicles, burned artwork, invaded residences and petrol-bombed the Vice-Chancellor's office. Eight students were arrested as the police attempted to restore order. Five students were suspended, the University obtained an interdict barring a further 16 from further protest, and charges were laid against the leaders of the RhodesMustFall campaign (Hall, 2016).

The Ministry of Higher Education condemned the burning of a bus at the University of the Witwatersrand, and damage to property and disruption at North-West University. The University of Pretoria planned to close two campuses amidst threats of a shutdown by some students and safety concerns (Badat, 2016). There were violent student protests at Walter Sisulu University, and at the University of KwaZulu-Natal (UKZN) protests continued on four campuses. As the tensions rose, some protesters resorted to violence, invading residences and residence kitchens; setting up burning barricades; burning portraits and other artwork stolen from residences; general vandalism; and intimidation of members of the campus community.

Matthews et al. (2013) aver that violence is inherited from a parent or is acquired from contemporaneous purveyors of violent ideologies. Such violence is learnt independently of the other characteristics of an overall belief system. Badat (2016) concurs and argues that the student protests mirror a number of features of contemporary South African society, including taking to the streets and destroying property.

East Africa has also experienced a wave of violent protests at its universities. Chuka University in Tharaka-Nithi County, Kenya was closed indefinitely as a result of student unrest over disputed student union elections. The police arrested 15 students who were looting shops at the nearby Ndagani market and forcing other businesses to close. Students also set a university bus ablaze 
amidst other acts of violence (Njeru, 2016). The University of Nairobi was also shut down indefinitely due to three days of student unrest. Students who had been looting and destroying property were asked to vacate the premises. News of the closure caught some students on Lower Kabete Campus off-guard and they again took to the streets to block roads opposing the move. Nairobi County Police Commander, Japheth Koome reported that eight machetes were found in a student's room on Chiromo Campus. This demonstrates the violent nature of student protest at African universities (Ombati, 2016).

In Burundi, the government closed all universities in April 2015 following student protests against the announcement that the incumbent President, Pierre Nkurunziza, would run for a third term in the presidential elections. The protests soon became violent as the police clashed with students in an attempt to disband them. Widespread demonstrations in the capital, Bujumbura, lasted for more than three weeks. The conflict led to the death of several students and police and dozens of students were arrested (Moore, 2015). Between 2011 and 2015, students at the University of Djibouti took to the streets on several occasions to protest against their grades and the country's poor education system and to prevent the president from seeking a third term. The 2015 protests turned violent. Daniel McCurry, a US citizen living and teaching in Djibouti reported that they "have taken the form of rock throwing, destruction of property, and general mayhem. The police have responded with arrests, tear gas" (Moore, 2015:1). Videos published by anonymous Djiboutian students on YouTube confirm these reports. The most violent confrontations were documented at the University of Djibouti, where only two out of 180 students had passed their exams. The students looted shops in downtown Djibouti City. Within the next few days, students from other universities joined the struggle. The police attempted to disperse them with teargas and students retaliated by throwing stones (Onyango-Obbo, 2015).

\section{Conclusion}

Students in Africa have inherited the culture of violence exhibited during the struggle against colonialism. While colonialism is "over", the culture of violence used to fight it has not disappeared. Rather, it is increasingly manifesting itself across the African continent. At the 2016 Strini Moodley Memorial Lecture held at UKZN delivered by the then University of the Free State Vice-Chancellor, Professor Jonathan Jansen, several students accused 
him and his counterpart at UKZN of abandoning the struggle for liberation and transformation and joining hands with the oppressors. At the same event, a student pointed out that when they (students) protest, burn buildings and destroy property, they consider it a victory. Violence has been used by generations in Africa as a way of resolving conflicts. While this is a single incident and does not necessarily represent the views of students across the continent, the fact that these students were representing a student organisation attests to the culture of violence they have inherited that is expressed in all facets of their lives.

African universities from Cape Town to Cairo are gradually becoming battle grounds where students wage war against one challenge or another in the fight for liberation. For this inherited ideological trait to be challenged and unpacked, different forms of engagement are required on different pathways for protest. Secondly, African universities need to create a culture to cater for student needs. Finally, when protests do occur, they should be addressed immediately, so as to reduce the potential for violent manifestations. The prevailing circumstances on the African continent as well as in African universities have strategically contributed in provoking this ideological trait. To deal with this, African governments and university structures must ensure that the educational landscape at African universities caters effectively for students' needs. Issues such as funding, basic social amenities, school management, and student representative council elections, amongst others, should be managed effectively so as to create the terrain for peaceful co-existence.

\section{References}

Abah, C \& Folarin, S 2016. UNILAG shut down over students protest. Punch, April 8. Lagos: Punchng.

Abercrombie, N, Adorno, T, Althusser, L \& Barrett, M 2012. Ideology Apparatus. In: S. Zizek (ed.). Mapping ideology. London: Verso.

Amine, K 2015. 'Arab Spring' and the performance of protest in Morocco and Tunisia. Francosphères 4(2):157-169.

Amutabi MN 2002. Crisis and student protest in universities in Kenya: Examining the role of students in national leadership and the democratization process. African Studies Review 45(02):157-177. 
Anderson, L 2011. Demystifying the Arab spring. Foreign Affairs 90(3):2-7.

Asante, MK 2014. The history of Africa: The quest for eternal harmony. London: Routledge.

Badat, S 2016. Deciphering the meanings, and explaining the South African Higher Education student protests of 2015-16. Johannesburg: University of Witswaterrand

Balsvik, RR 1998. Student Protest-University and State in Africa 1960-1995. Forum for Development Studies 25:301-325.

Bawa, A 2016. Universities SA condemns incidents of arson at public universities. Pretoria: Universities South Africa.

Beattie, P 2017. The "chicken-and-egg" development of political opinions: The roles of genes, social status, ideology, and information. Politics and the Life Sciences 36(1):1-13.

Beissinger, MR, Jamal, A, \& Mazur, K 2012. Who participates in democratic Revolutions? A comparison of the Egyptian and Tunisian Revolutions. Social Science Research Network Working Paper Series, 16 July 2012.

Bell, E, Schermer, JA \& Vernon, PA 2009. The origins of political attitudes and behaviours: An analysis using twins. Canadian Journal of Political Science 42(4):855-879.

Bellei, C, Cabalín, C \& Orellana, V 2014. The 2011 Chilean student movement against neoliberal educational policies. Studies in Higher Education 39(3):426-440.

Bening, R 2014. Integration and disintegration in British colonial West Africa: The case of the Gold Coast and Lagos 1874-1886. Ghana Journal of Geography 1(1):1-16.

Biuso, E. 2008. “Genopolitics”. New York Times Magazine, 57. New York: The New York Times Company.

British Broadcasting Cooperation 2000. Protests at Gambia killings. British Broadcasting Cooperation, April 11.

Charney, E \& English, W 2012. Candidate genes and political behavior. American Political Science Review 106(1):1-34.

Cheru, F 2002. African renaissance: Roadmaps to the challenge of globalization. Cape Town: New Africa Books.

Chimanikire, DP 2009. Youth and Higher Education in Africa: The cases of Cameroon, South Africa, Eritrea, and Zimbabwe. Nairobi: African Books Collective.

Collado, ÁS 2013. The amazigh movement in Morocco: New generations, new references of mobilization and new forms of opposition. Middle East Journal of Culture and Communication 6(1):55-74. 
David, A 2013. Students' crisis in Nigerian tertiary educational institutions: A review of the causes and management style. Khazar Journal of Humanities \& Social Sciences 16(1):56-76.

DeLancey, MD, Mbuh, R \& DeLancey, MW 2010. Historical dictionary of the Republic of Cameroon. Maryland: Scarecrow Press.

Duhan, J 2013. Vive le Proletariat: The 1968 Revolt of French Workers and Students. Michigan: Western Michigan University.

Eaves, LJ \& Eysenck, HJ 1974. Genetics and the development of social attitudes. Nature 249(54):288-289.

Eaves, LJ, Eysenck, HJ \& Martin, NG 1989. Genes, culture and personality: An empirical approach. San Diego, CA: Academic Press.

Federici, S \& Caffentzis, G 2000. Chronology of African university students' struggles: 1985-1998. In: S Federici, G Caffentzis \& O Alidou (ed.). A thousand flowers: Social struggles against structural adjustment in African universities. Trenton: Africa World Press.

Fomunyam, GK 2017. Education as politics in the context of Operation Ghost Town in Southern Cameroon. Knowledge for Transformation 1(1):1-4.

Fomunyam, KG \& Rahming M 2017. Knowledge as power for social transformation. Zoe International Journal of Social Transformation 1(1):1-6.

Fowler, JH \& Dawes, CT 2013. In defense of genopolitics. American Political Science Review $107(2): 362-374$.

Gerbaudo, P 2015. Protest avatars as memetic signifiers: Political profile pictures and the construction of collective identity on social media in the 2011 protest wave. Information. Communication \& Society 18(8):916-929.

Giroux HA 2013. The Quebec student protest movement in the age of neoliberal terror. Social Identities 19(5):515-535.

Gorgas, JT 2013. The limits of the state: Student protest in Egypt, Iraq and Turkey, 1948-63. British Journal of Middle Eastern Studies 40(4):359-377.

Hale, S \& Kadoda, G 2014. The changing nature of political activism in Sudan: women and youth 'activists' as catalysts in civil society. In: E Grawert. Forging two nations: Insights on Sudan and South Sudan. Berlin: African Books Collective.

Hall, M 2016. South Africa's student protests have lessons for all universities. Higher Education Network, 3 March. 
Halpern, M 2015. Politics of social change: In the Middle East and North Africa. Princeton: Princeton University Press.

Hatemi, PK \& McDermott, R 2012a. The genetics of politics: Discovery, challenges, and progress. Trends in Genetics 28(10):525-533.

Hatemi, PK \& McDermott, R 2012b. A neurobiological approach to foreign policy analysis: Identifying individual differences in political violence. Foreign Policy Analysis 8(2):111-129.

Hatemi, PK, Medland, SE, Klemmensen, R, Oskarsson, S, Littvay, L, Dawes, CT, Verhulst, B, McDermott, R, Nørgaard, AS, Klofstad, CA \& Christensen, K 2014. Genetic influences on political ideologies: Twin analyses of 19 measures of political ideologies from five democracies and genome-wide findings from three populations. Behavior Genetics, 44(3):282-294.

Isaacman, A 1990. Peasants and rural social protest in Africa. African Studies Review, 33(2): $1-120$.

Joseph, J 2010. The genetics of political attitudes and behavior: Claims and refutations. Ethical Human Psychology and Psychiatry, 12(3):200-217.

Karmo, H 2016. University of Liberia students petition legislature over tuition increment. Front Page Africa, 20 April.

Khama, K 2010. Limkokwing students strike. Lesotho Times, September 15.

Kim, P 2008. Chinese student protests: Explaining the student movements of the 1980s and the lack of protests since 1989. Berkeley Undergraduate Journal 21(2):1-42.

Kohstall, F 2015. From reform to resistance: Universities and student mobilisation in Egypt and Morocco before and after the Arab uprisings. British Journal of Middle Eastern Studies 42(1):59-73.

Konings P 2002. University students' revolt, ethnic militia, and violence during political liberalization in Cameroon. African Studies Review, 45(2):179-204.

Kovač, S 2016. History of Africa. Issues in Ethnology and Anthropology 1(1):203-205.

Kubal, MR \& Fisher, E 2016. The Politics of student protest and education reform in Chile: Challenging the neoliberal state. The Latin Americanist 60(2):217-242.

Kurbatova, T 2017. Basic features of conceptual sphere "Geopolitics" in modern Englishspeaking worldview. In: E Piechurska-Kuciel, E Szymańska-Czaplak \& M Szyszka (eds.). At the Crossroads: Challenges of foreign language learning. Cham: Springer International Publishing. 
Kurtz, L 2008. Czechoslovakia's velvet revolution 1989: Summary of events related to the use. International Center on Nonviolent Conflict 5(1):1-6.

Lea, J 2013. Book review symposium: Steven Pinker, the better angels of our nature: A History of violence and humanity. Sociology 47(6):1226-1227.

Lusaka Times 2016. Kaingu closes UNZA, CBU indefinitely. 3 February.

Lyons, DE 2008. The rational continuum of human imitation. In: JA Pineda (ed.). Mirror neuron systems. New York: Humana Press.

Lyons, DE, Damrosch, DH, Lin JK, Macris, DM \& Keil, FC 2011. The scope and limits of overimitation in the transmission of artefact culture. Philosophical transactions of the Royal Society of London B: Biological Sciences, 366(1567): 1158-1167.

MacGregor, K 2011. Lomé campus closed after student violence. Radio France Internationale, 5 June.

MacGregor K 2014. Student protests in Burundi and Cote d'Ivoire. University World News, 11 April.

Magzan, M 2009. Social sense and effect of music: Prevailing ideology in music curricula in Croatia before and after its independence. Zagreb: Verlag.

Malila, V \& Garman, A 2016. Listening to the 'Born Frees': Politics and disillusionment in South Africa. African Journalism Studies 37(1):64-80.

Mamdani, M 2003. Making sense of political violence in postcolonial Africa. Socialist Register 39(2):132-151.

Martin, NG, Eaves, LJ, Heath, AC, Jardine, R, Feingold, LM, \& Eysenck, HJ 1986. Transmission of social attitudes. Proceedings of the National Academy of Sciences, 83(12):4364-4368.

Marx, K \& Engels, F 1980. Marx \& Engels Collected Works, Vol 13. London: Lawrence \& Wishart.

Matthews, LJ, Edmonds, J, Wildman, WJ \& Nunn, CL 2013. Cultural inheritance or cultural diffusion of religious violence? A quantitative case study of the radical reformation. Religion, Brain \& Behavior 3(1):3-15.

Maxfield, MG \& Widom CS 1996. The cycle of violence: Revisited 6 years later. Archives of Pediatrics \& Adolescent Medicine 150(4):390-395.

Mfula, C 2016. Zambia closes two government universities after student protests. Reuters Africa, 4 February. 
Moore, P 2015. Burundi student protesters seek refuge in US embassy. Al Jazeera, June 25.

Njeru, A 2016. Chuka University Shut Down Over Student Uproar. All Africa, 8 February.

Njoh, AJ \& Bigon, L 2015. Germany and the deployment of urban planning to create, reinforce and maintain power in colonial Cameroon. Habitat International, 49:10-20.

Ombati, C 2016. University of Nairobi closed indefinitely following three days of student protests. Standard Media, 6 April.

Omonijo, DO, Oludayo, OO, Uche, O, \& Eche, D 2014. Violent protest in private universities in Nigeria: Implications for educational development. European Journal of Social Sciences, 45(4):352-359.

Onyango-Obbo, C 2015. The Ethiopian and Djibouti protests; people don't live on bread and wine alone, they need sweet lies too. Mail and Guardian Africa, 30 December.

Prosser, MH \& Sitaram, K 2014. Civic discourse: Intercultural, international, and global media. Stamford: Greenwood Publishing Group.

Radina, R 2013. Student protest. In: T Poetter (ed.). Curriculum Windows: What curriculum theorists of the 1960s can teach us about schools and society today. North Carolina: Information Age Publishing.

Rooney, R 2011. Students protest during Swazi festival. South Africa Press Association, 25 August.

Shultziner, D 2013. Genes and politics: A new explanation and evaluation of twin study results and association studies in political science. Political Analysis 21(3):350-367.

Smith, K, Alford, JR, Hatemi, PK, Eaves, LJ, Funk, C \& Hibbing, JR 2012. Biology, ideology, and epistemology: How do we know political attitudes are inherited and why should we care? American Journal of Political Science 56(1):17-33.

Smith KB, Oxley DR, Hibbing MV, Alford, JR \& Hibbing, JR 2011. Linking genetics and political attitudes: Reconceptualizing political ideology. Political Psychology, 32(3):369-397.

Ugbodaga, K 2016. UI students protest, shut down school. The News, 26 April.

Weiland KL, Guzman A \& O’Meara K. 2013. Politics, identity, and college protest: Then and now. About Campus, 18(2):2-9.

Zambakari, C 2014. Nation and state building in south Sudan: Violence, development, and democracy. Business, Peace and Sustainable Development 3:162-178. 
Zeilig, L \& Dwyer, P 2012. African struggles today: Social movements since independence. Chicago: Haymarket Books.

Zeleza, PT 2012. The African struggle continues: The awakening of North Africa. Canadian Journal of African Studies / La Revue Canadienne Des Etudes Africaines, 46(1):129137.

Žižek, S 1999. The spectre of ideology. In: E Wright \& E Wright (eds.). The Žižek Reader. Oxford: Blackwell Publishers. 